\title{
ISOLASI DAN IDENTIFIKASI SENYAWA ANTIFUNGAL AKAR Acacia mangium DAN AKTIVITASNYA TERHADAP Ganoderma lucidum
}

\author{
(Isolation and Identification of Antifungal Compound from Acacia mangium Root and Its Effect \\ on Ganoderma lucidum)
}

\author{
Nur Hidayati ${ }^{1}$, SM Widyastuti ${ }^{2}$, Subagus Wahyuono ${ }^{3}$ \\ ${ }^{1}$ Balai Besar Penelitian Bioteknologi dan Pemuliaan Tanaman Hutan \\ E-mail: inunghidayati@yahoo.com \\ ${ }^{2}$ Fakultas Kehutanan Universitas Gadjah Mada \\ ${ }^{3}$ Fakultas Farmasi Universitas Gadjah Mada
}

Tanggal diterima: 10 Februari 2012; Direvisi: 22 Februari 2012; Disetujui terbit: 31 Mei 2012

\begin{abstract}
Acacia mangium has been planted on large scale of industrial forest plantation in Indonesia, especially in Sumatera and Kalimantan islands. It has been reported that huge number of mangium plantations on those areas infected rot root disease caused by Ganoderma lucidum. To date, there was no information of mangium which resist to Ganoderma lucidum Moreover, research to get this information had been carried out with two aims as listed below: (1) isolate and identify a compound with antifungal properties from the roots of healthy mangium, and (2) identify the effect of the antifungal compound from roots of healthy mangium on Ganoderma lucidum

The roots of healthy mangium from the first generation of seedling seed orchard in Wonogiri, Central Java, were used as material of this research. Mangium roots which had had their external and internal parts separated were macerated in a solvent of n-hexane and methanol. Methods of the isolation of the antifungal compound were the thinlayer chromatography (TLC), column chromatography and thin layer preparative chromatography. Antifungal effect test was carried out by using inhibition of germination and of hyphal growth of Fusarium sp. Ultraviolet (UV) spectrometry, Infrared (IR) and Gas Chromatography - Mass Spectrometry (GC-MS) were used to identify the antifungal compound. Antifungal effect test on Ganoderma lucidum was done with a modification of the cylinder plate method, performed in vitro.

The results revealed that the antifungal compound succeed isolated in its Substance B form from methanol extract from the interior of the root. Substance B showed the highest level of antifungal activity through inhibiting germination and inhibiting of germination tube growth of Fusarium sp. This was shown by the highest percentage inhibiting of germination (66,67\%), and the highest percentage inhibiting of germination tube (66,03\%). The inhibition zone of hyphal growth of Ganoderma lucidum macroscopically from the antifungal compound was observed at a concentration of $1800 \mu \mathrm{g} / \mathrm{ml}$. Microscopically, in the area of contact with the antifungal compound, hyphal curling and distorting of tips took place at a concentration of $1500 \mu \mathrm{g} / \mathrm{ml}$ one day after application of the antifungal compound. Based on the analysis of GC-MS spectra, the antifungal was identified as p-Methoxybenzylidene p-aminophenol in the category of phenolic compounds.
\end{abstract}

Key words: Acacia mangium, antifungal compound, Ganoderma lucidum, p-Methoxybenzylidene p-aminophenol

\footnotetext{
ABSTRAK

Tujuan penelitian ini adalah untuk (1) mengisolasi dan mengidentifikasi senyawa yang bersifat antifungal dari akar mangium sehat, (2) mengetahui aktivitas senyawa antifungal dari akar mangium sehat terhadap Ganoderma lucidum

Penelitian ini menggunakan materi berupa akar mangium sehat dari kebun benih mangium generasi pertama di Wonogiri Jawa Tengah. Akar mangium yang telah dipisahkan antara bagian luar dan bagian dalam dimaserasi dengan
} 
pelarut n-heksana dan metanol. Isolasi senyawa antifungal menggunakan metode kromatografi lapis tipis, kromatografi kolom dan kromatografi lapis tipis preparatif. Uji aktivitas antifungal dilakukan dengan menggunakan penghambatan perkecambahan dan penghambatan buluh kecambah Fusarium sp. Identifikasi senyawa dengan analisis spektrometri Ultra violet (UV), Infrared (IR) serta Gas Chromatography-Mass Spectrometry (GC-MS). Uji aktivitas antifungal terhadap Ganoderma lucidum dilakukan dengan modifikasi metode cylinder plate secara in-vitro.

Senyawa antifungal berhasil diisolasi dari substansi B ekstrak metanol akar mangium sebelah dalam. Substansi B menunjukkan aktivitas antifungal tertinggi pada penghambatan kecambah sebesar 66,67\% dan penghambatan pembentukan buluh kecambah konidia Fusarium sp. tertinggi sebesar 66,03\%. Zona penghambatan pertumbuhan hifa Ganoderma lucidum secara makroskopis oleh senyawa antifungal teramati pada konsentrasi $1800 \mu \mathrm{g} / \mathrm{ml}$. Secara mikroskopis, pada daerah kontak dengan senyawa antifungal, hifa menyimpang serta berbentuk ikal pada ujungnya pada konsentrasi $1500 \mu \mathrm{g} / \mathrm{ml}$ sehari setelah aplikasi senyawa antifungal. Hasil identifikasi dengan GC-MS, senyawa antifungal ini teridentifikasi sebagai p-Methoxybenzylidene p-aminophenol termasuk dalam golongan senyawa fenolik.

Kata Kunci : Acacia mangium, senyawa antifungal, Ganoderma lucidum, p-Methoxybenzylidene p-aminophenol

\section{PENDAHULUAN}

Perubahan ekosistem hutan dari alam ke tanaman yang kebanyakan monokultur atau campuran terbatas dapat meningkatkan serangan organisme patogenik. Saat ini dilaporkan Ganoderma sp., penyebab penyakit busuk akar banyak menyerang pertanaman HTI mangium terutama di Sumatera dan Kalimantan. Penyakit ini merupakan salah satu penyakit paling merugikan yang menyerang pertanaman mangium. Di Sumatera pada rotasi kedua pertanaman HTI, serangan patogen busuk akar telah mencapai 3-25\% (Rimbawanto, 2006).

Salah satu mekanisme pertahanan pada tanaman akibat serangan patogen penyebab penyakit adalah peningkatan kadar senyawa kimia tertentu pada tanaman akibat respon terhadap serangan patogen penyebab penyakit (Agrios, 2005). Tanaman memproduksi metabolit sekunder berupa senyawa antimikrobia, baik dalam pertumbuhan normal maupun dalam keadaan terinfeksi patogen atau tekanan abiotik. Metabolit sekunder ini memungkinkan tanaman dapat bertahan terhadap penyakit (Morrisey dan Osbourn, 1999). Salah satu reaksi jaringan tumbuhan terhadap infeksi oleh mikroorganisme ialah peningkatan sintesis senyawa fenolik. Ini kemungkinan merupakan upaya perlindungan tanaman terhadap serangan mikroorganisme penyebab penyakit walaupun usaha ini belum tentu dapat mencegah terinfeksinya jaringan tanaman oleh mikroorganisme penyebab penyakit tersebut (Harborne, 1996). Tanaman memproduksi metabolit sekunder antimikrobia sebagai bagian dari pertumbuhan dan perkembangan tanaman secara normal, maupun sebagai respon terhadap serangan patogen. Beberapa senyawa yang tergolong metabolit sekunder yang mengandung senyawa 
antimikrobia adalah senyawa-senyawa polifenol, glikosida dan saponin (Widyastuti, 2001 dan Abad et al., 2007).

Senyawa polifenol ditemukan pada tanaman-tanaman tingkat tinggi (Haslam,1988) dan mempunyai kemampuan melindungi jaringan tanaman dari pengaruh lingkungan luar termasuk pengaruh sebagai antimikrobia (Scalbert, 1991; Mila et al., 1996) dan antioksidan (Hagerman et al., 1998). Pada tanaman berkayu senyawa polifenol terakumulasi di dalam kulit batang, daun dan bagian empulur (heartwood). Ekstrak kulit batang dan empulur dari beberapa spesies tanaman berkayu mempunyai aktivitas antioksidan (Chang et al., 2001) dan aktivitas antifungal (Kishino et al., 1995).

Pengendalian penyakit akar merah dengan cara pemilihan tanaman tahan belum banyak dilaporkan sebelumnya. Salah satu faktor yang menyebabkan tanaman tahan terhadap suatu penyakit tertentu adalah adanya metabolit sekunder yang berupa senyawasenyawa pra-infeksi. Tanaman mempunyai substansi berupa senyawa kimia yang bersifat menghambat penyebab penyakit sebelum dan setelah terjadinya infeksi. Senyawa pra-infeksi yang merupakan metabolit sekunder dari tanaman, dianggap penting sebagai penyebab ketahanan tanaman terhadap penyakit. Tujuan dari penelitian ini adalah untuk mengisolasi dan mengidentifikasi senyawa yang bersifat antifungal dari akar mangium sehat serta mengetahui aktivitasnya terhadap Ganoderma lucidum.

\section{ALAT, BAHAN DAN METODE PENELITIAN}

\section{A. Isolat Ganoderma lucidum dan}

Fusarium sp.

Badan buah Ganoderma lucidum diambil dari pangkal batang tanaman mangium sakit di kebun benih mangium generasi pertama, Wonogiri, Jawa Tengah. Identifikasi jenis jamur dilakukan secara morfologi terhadap badan buah jamur dan isolat hasil isolasi badan buah jamur. Sedangkan Fusarium sp. yang digunakan merupakan koleksi dari laboratorium Perlindungan dan Kesehatan Hutan, Fakultas Kehutanan UGM yang diisolasi dari semai tanaman mangium. Isolat ditumbuhkan pada media PDA (Potato Dekstrose Agar) dengan konsentrasi 23,4 gr/600ml.

\section{B. Isolasi dan identifikasi senyawa antifungal}

Sampel berupa akar mangium diambil dari kebun benih mangium generasi pertama umur 13 tahun di Wonogiri, Jawa Tengah.

\section{1) Ekstraksi sampel akar mangium}

Metode ekstraksi sampel yang digunakan pada penelitian ini mengacu pada metode Cannell (1998) yaitu dengan cara maserasi. Sampel berupa akar dengan nomor famili 139 dipisahkan antara bagian dalam dan bagian luar kemudian masing-masing bagian ini 
digiling hingga diperoleh serbuk halus. Lima ratus gram serbuk akar dimaserasi dengan 3 liter n-heksana selama 24 jam, kemudian disaring dengan kertas saring dan hasilnya ditampung pada cawan porselen. Residu n-heksana dimaserasi lagi dengan n-heksana sebanyak 3 liter selama 24 jam. Hasilnya disaring dan digabungkan pada cawan porselen yang pertama, dan ekstrak diuapkan sampai kering. Residu n-heksana ini kemudian dimaserasi dengan metanol sebanyak 3 liter selama 24 jam, hasil saringannya ditampung pada cawan porselen yang kedua. Ekstrak metanol yang diperoleh dipekatkan dengan rotary evaporator hingga volume tertentu. Tahap ini menghasilkan 2 ekstrak yaitu ekstrak n-heksana dan ekstrak metanol. Masing-masing ekstrak kemudian dilihat profilnya melalui KLT dan diuji aktivitas antifungalnya dengan fungi uji Fusarium sp.

\section{2) Uji aktivitas antifungal terhadap Fusarium sp.}

Pengujian aktivitas antifungal masingmasing ekstrak dilakukan pada Fusarium sp. dengan menggunakan modifikasi metode Widyastuti et al., (1998).

Pengujian dilakukan dengan cara :

- Media Water agar (WA) sebanyak $2 \mathrm{ml}$ ditambah dengan suspensi Fusarium sp. pengenceran $10^{-3}$ sebanyak $1 \mathrm{ml}$.
- Media WA dipotong-potong setelah dingin, dengan ukuran 1 x $1 \mathrm{~cm}$ dan diletakkan pada gelas benda cekung. Potongan media WA pada gelas benda ditetesi dengan $50 \mu \mathrm{L}$ larutan ekstrak/fraksi/senyawa kemudian diinkubasikan selama 8 jam (agar lebih dari 50\% konidia Fusarium sp. yang berkecambah). WA yang telah diinkubasi ditetesi dengan lacthophenol cotton blue dan dihitung persentase perkecambahan konidia.

Parameter yang diamati dalam pengujian ini adalah :

- Persentase penghambatan kecambah

Konidia Fusarium sp. yang diamati sebanyak 100 dengan 3 ulangan. Persentase penghambatan kecambah konidia Fusarium sp. dihitung dengan rumus :

Jumlah konidia yang tidak berkecambahX100\% 100 konidia

- Persentase penghambatan pembentukan buluh kecambah

Pengamatan panjang buluh kecambah diamati dari 100 konidia yang berkecambah tiap perlakuan. Penghitungan persentase penghambatan pembentukan buluh kecambah dihitung dengan rumus :

\section{Rata-rata panjang buluh kontrol - Rata-rata panjang buluh kecambah dari 100 konidia $\quad$ X 100\%}




\section{3) Kromatografi lapis tipis (KLT)}

Teknik KLT yang digunakan pada penelitian ini mengacu kepada metode yang dikembangkan

Moffat

(1986).

Ekstrak/fraksi/senyawa aktif yang menunjukkan aktivitas antifungal dilihat profilnya melalui KLT menggunakan plat aluminium $\mathrm{GF}_{254}$ (Emerck) dengan fase diam silika gel dan fase gerak n-heksana : etil asetat dengan perbandingan tertentu untuk memisahkan dan menguji senyawa-senyawa yang terkandung dalam ekstrak/fraksi/senyawa aktif dalam bentuk spot-spot yang terpisah. Spot-spot yang terbentuk pada plat KLT diamati di bawah sinar UV dengan panjang gelombang 254 nm dan 366 nm. Selanjutnya plat KLT disemprot menggunakan pereaksi semprot serium (IV) sulfat dan dioven selama 15 menit pada suhu $110^{\circ} \mathrm{C}$.

\section{4) Pemisahan dengan kromatografi kolom (fraksinasi)}

Metode yang digunakan pada penelitian

ini adalah menggunakan kromatografi kolom yang mengacu pada metode yang digunakan Waters (1985). Silika gel $\mathrm{PF}_{254}$ digunakan sebagai fase diam. Sedangkan fase gerak yang digunakan menggunakan sistem fase gerak dengan polaritas bertingkat. Masing-masing fraksi yang telah dipisahkan, dimonitor profilnya melalui KLT menggunakan plat aluminium $\mathrm{GF}_{254}$ (E-merck) dengan fase diam silika gel dan fase gerak n-heksana : etil asetat $(18: 3 \mathrm{ml})+0,5 \mathrm{ml}$ asam asetat glasial

\section{5) Kromatografi lapis tipis preparatif}

Kromatografi lapis tipis preparatif menggunakan plat kaca berukuran 20 x $20 \mathrm{~cm}$ dengan fase diam silika gel $\mathrm{PF}_{254}$ yang telah diaktifkan dengan memanaskan selama satu jam pada suhu $110^{\circ} \mathrm{C}$. Fraksi aktif yang telah dilarutkan pada pelarut metanol : kloroform (1 : $1, \mathrm{v} / \mathrm{v})$ diteteskan memanjang membentuk pita pada plat kaca dan dielusi dengan fase gerak nheksana : etil asetat $(60: 60 \mathrm{ml})+3,6 \mathrm{ml}$ asam asetat glasial. Plat kaca dikeringkan dan diamati dengan sinar UV dengan panjang gelombang $254 \mathrm{~nm}$ dan $366 \mathrm{~nm}$. Pengambilan senyawa hasil KLT preparatif dengan cara dikerik dan hasilnya dilarutkan dengan pelarut metanol : kloroform (9 : 1, v/v) kemudian dikeringkan.

\section{6) Identifikasi senyawa antifungal}

Identifikasi senyawa pada penelitian ini dilakukan guna menentukan golongan senyawa, sifat fisiknya dan struktur senyawa. Penyemprotan dilakukan pada senyawa antifungal dengan penyemprot spesifik untuk memberikan informasi tentang golongan senyawa. Sedangkan pendekatan struktur aktif dilakukan dengan menggunakan metode spektroskopi UV, IR dan GC-MS.

\section{Uji aktivitas senyawa antifungal terhadap Ganoderma lucidum \\ Pengujian aktivitas ini dilakukan dengan} menggunakan modifikasi cylinder plate methode (Johnson dan Curl, 1972) dengan cara 
membuat sumuran-sumuran pada media kultur. Ganoderma lucidum. ditumbuhkan pada media Water Agar. Setelah koloni Ganoderma lucidum. berdiameter kira-kira 3 - $4 \mathrm{~cm}$, sumuran-sumuran ini diisi dengan larutan senyawa dengan konsentrasi yang berbeda (300, 600, 900, 1200, 1500 dan $1800 \mu \mathrm{g} / \mathrm{ml})$. Sebagai kontrol digunakan air steril dan DMSO 5\%. Pengamatan dilakukan secara makroskopis dengan melihat zona penghambatan pertumbuhan miselium Ganoderma lucidum oleh senyawa antifungal. Pengamatan secara mikroskopis dilakukan pada daerah hambatan antara koloni Ganoderma lucidum dan senyawa antifungal dengan menggunakan mikroskop.

\section{Analisis Data}

Pengamatan persentase perkecambahan dan panjang buluh kecambah konidia Fusarium sp. dilakukan dengan menggunakan mikroskop (merek Carl Zeiss) perbesaran 40X dengan program Axio Vision. Persentase kecambah dan panjang buluh kecambah konidia Fusarium sp. dihitung menggunakan program Microsoft Excel 2003. Data disajikan dalam bentuk diagram batang berdasarkan nilai rata-rata. Zona penghambatan senyawa antifungal terhadap Ganoderma lucidum diamati secara makroskopis dan data disajikan dalam foto-foto.

\section{HASIL DAN PEMBAHASAN}

\section{A. Ekstrak Akar Mangium}

Tahap ini menghasilkan dua ekstrak yaitu ekstrak n-heksana dan ekstrak metanol. Masing-masing ekstrak kemudian diuji aktivitas antifungalnya dengan fungi uji Fusarium sp.

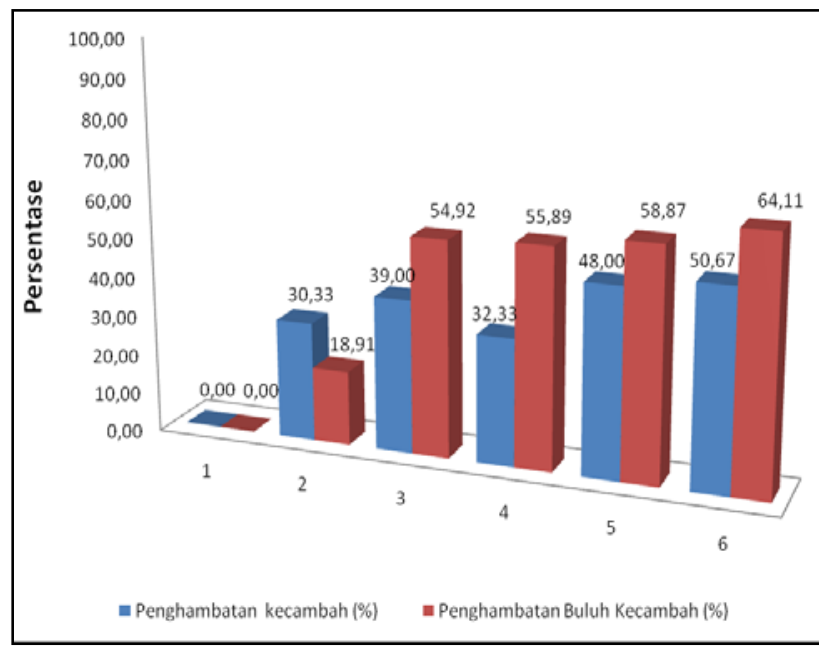

Gambar 1.Rata-rata aktivitas ekstrak n-heksana dan metanol terhadap penghambatan kecambah dan pembentukan panjang buluh kecambah konidia Fusarium sp. yang diuji pada konsentrasi $500 \mu \mathrm{g} / \mathrm{ml}$

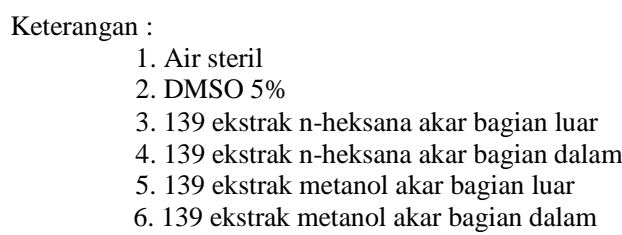

Gambar 1 menunjukkan adanya variasi hasil dalam uji aktivitas antifungal. Penghambatan kecambah terendah adalah 0\% sedangkan penghambatan kecambah tertinggi adalah 50,67\%. Penghambatan pembentukan buluh kecambah terendah yang dihasilkan pada perlakuan ini adalah $0 \%$ sedangkan penghambatan pembentukan panjang buluh 
kecambah tertinggi adalah 64,11\%. Aktivitas antifungal pada penghambatan kecambah dan penghambatan buluh kecambah Fusarium sp. tertinggi ditunjukkan oleh ekstrak metanol bagian akar sebelah dalam.

Ekstrak dari akar mangium bagian dalam memiliki kemampuan dalam menghambat perkecambahan konidia Fusarium sp. yang lebih tinggi daripada akar bagian luar. Pada umur tertentu, kayu bagian dalam suatu batang tanaman kebanyakan pohon mulai berubah menjadi kayu teras yang mati seluruhnya dan proporsinya dalam batang menjadi semakin besar dengan pertumbuhan pohon. Kayu teras memiliki zat ekstraktif yang lebih banyak daripada kayu gubal sehingga menyebabkan kayu teras lebih tahan terhadap serangan serangga maupun fungi (Sjostrom, 1998).

Penghambatan perkecambahan konidia dan penghambatan hifa konidia Fusarium sp. terbesar dihasilkan dari perlakuan ekstrak metanol dibandingkan ekstrak n-heksana. Menurut Gritter et al., (1991) metanol merupakan pelarut dengan polaritas lebih tinggi dibandingkan dengan n-heksana. Metanol merupakan pelarut polar yang sering digunakan karena penetrasi ke dalam dinding sel lebih efisien, sehingga menghasilkan metabolit sekunder endoselular lebih banyak.

\section{B. Fraksi-Fraksi Ekstrak Aktif}

Ekstrak metanol akar bagian dalam mempunyai aktivitas antifungal tertinggi terhadap konidia Fusarium sp. Ekstrak ini selanjutnya difraksinasi dengan kromatografi kolom yang menghasilkan 12 fraksi (Gambar 2).

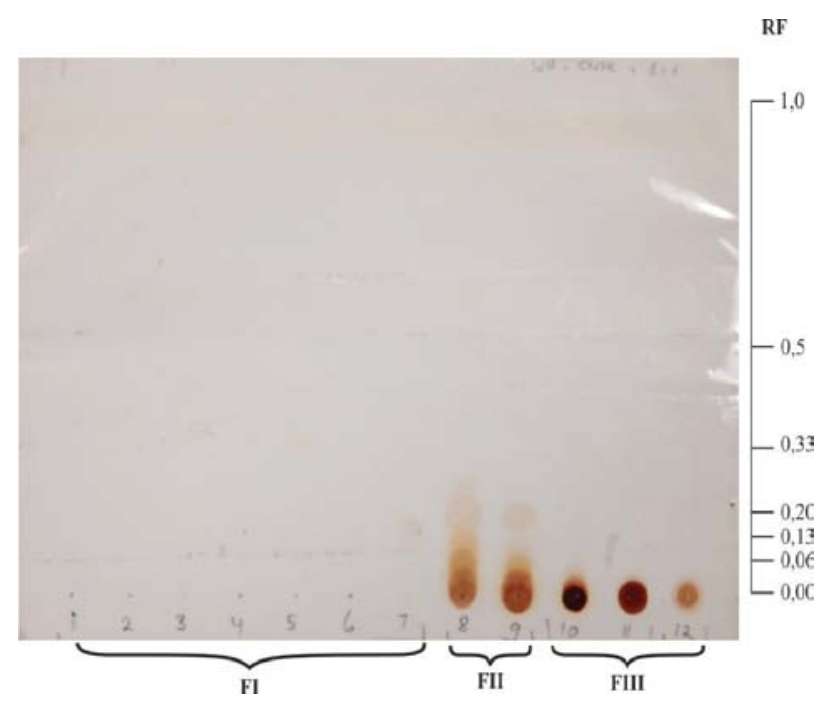

Gambar 2. Kromatografi lapis tipis masingmasing fraksi akar tanaman mangium sebelah dalam ffase diam silika gel $\mathrm{GF}_{254}$ dan fase gerak n-heksana : etil asetat (18: 3 $\mathrm{ml})+0,5 \mathrm{ml}$ asam asetat glasial $\}$

Keterangan :

$$
\begin{aligned}
& \text { FI : Fraksi } 1-7 \\
& \text { FII : Fraksi } 8-9 \\
& \text { FIII : Fraksi } 10-12
\end{aligned}
$$

Fraksi-fraksi yang menunjukkan pemisahan spot yang serupa digabung dan kemudian diuapkan sampai kering. Fraksi hasil gabungan kemudian dilakukan uji aktivitas antifungal dengan fungi uji Fusarium sp. Demikian seterusnya hingga diperoleh senyawa murni. Hasil penggabungan di sebut Fraksi I (1-7), Fraksi II (8-9) dan Fraksi III (10-12).

Hasil dari uji aktivitas antifungal menghasilkan Fraksi II mempunyai aktivitas tertinggi terhadap penghambatan kecambah konidia Fusarium sp. sebesar $71 \%$ dan 
penghambatan pembentukan buluh kecambah konidia terendah sebesar 56,47\% (Gambar 3). Fraksi II mempunyai aktivitas penghambatan konidia Fusarium sp. paling tinggi dibandingkan dengan fraksi lainnya.

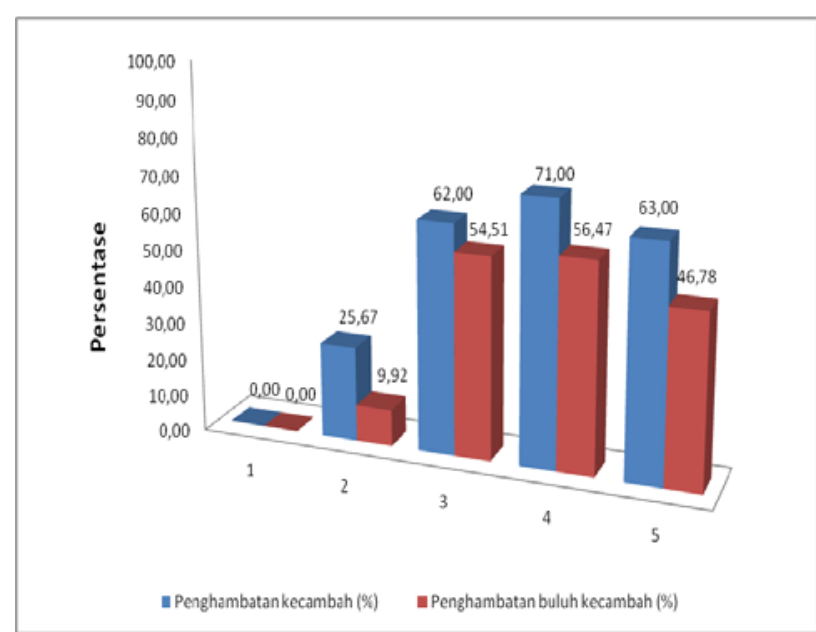

Gambar 3. Rata-rata aktivitas hasil fraksinasi ekstrak metanol akar bagian dalam terhadap penghambatan kecambah dan pembentukan panjang buluh kecambah konidia Fusarium sp. yang diuji pada konsentrasi 500 $\mu \mathrm{g} / \mathrm{ml}$

Keterangan :
1. Air steril
4. Fraksi II
2. DMSO 5\%
5. Fraksi III
3. Fraksi I

\section{Senyawa Antifungal}

Kromatografi lapis tipis preparatif dilakukan untuk mengisolasi senyawa-senyawa tunggal yang ada pada fraksi aktif. Pengambilan senyawa hasil KLT preparatif dengan cara dikerok .dan dipisahkan antara bagian atas (substansi A), bagian tengah (substansi B) dan bagian bawah (substansi C) .
Hasil dari uji aktivitas antifungal menghasilkan substansi B memiliki aktivitas antifungal tertinggi dalam penghambatan perkecambahan dan penghambatan konidia Fusarium sp. Substansi ini mempunyai aktivitas terhadap penghambatan kecambah konidia Fusarium sp. sebesar $66,67 \%$ dan penghambatan pembentukan buluh kecambah sebesar 66,03\% (Gambar 4).

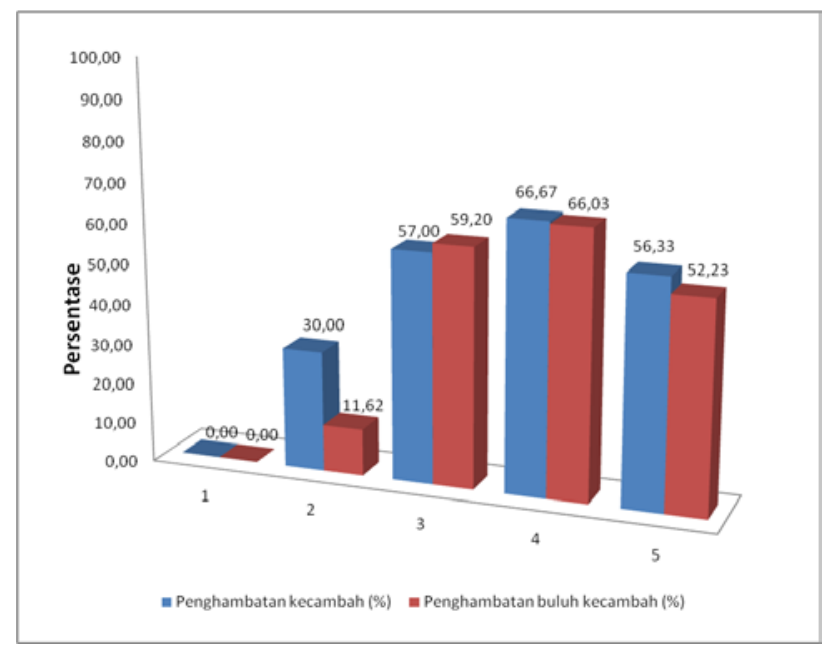

Gambar 4. Rata-rata aktivitas hasil KLT preparatif terhadap penghambatan kecambah dan pembentukan buluh kecambah konidia Fusarium sp. yang diuji pada konsentrasi 500 $\mu \mathrm{g} / \mathrm{ml}$

Keterangan :
1. Air steril
4. Substansi B
2. DMSO 5\%
5. Substansi C

3. Substansi A

Pengujian kemurnian senyawa antifungal dilakukan dengan KLT menggunakan beberapa fase gerak yang memiliki polaritas yang berbeda (Gambar 5). Sukadana et al., (2008) menyatakan bahwa bila suatu fraksi atau senyawa diuji kemurniannya dengan 
menggunakan beberapa eluen yang berbeda senyawa tersebut dapat dikatakan isolat relatif tetap menghasilkan satu spot maka fraksi atau murni secara KLT.

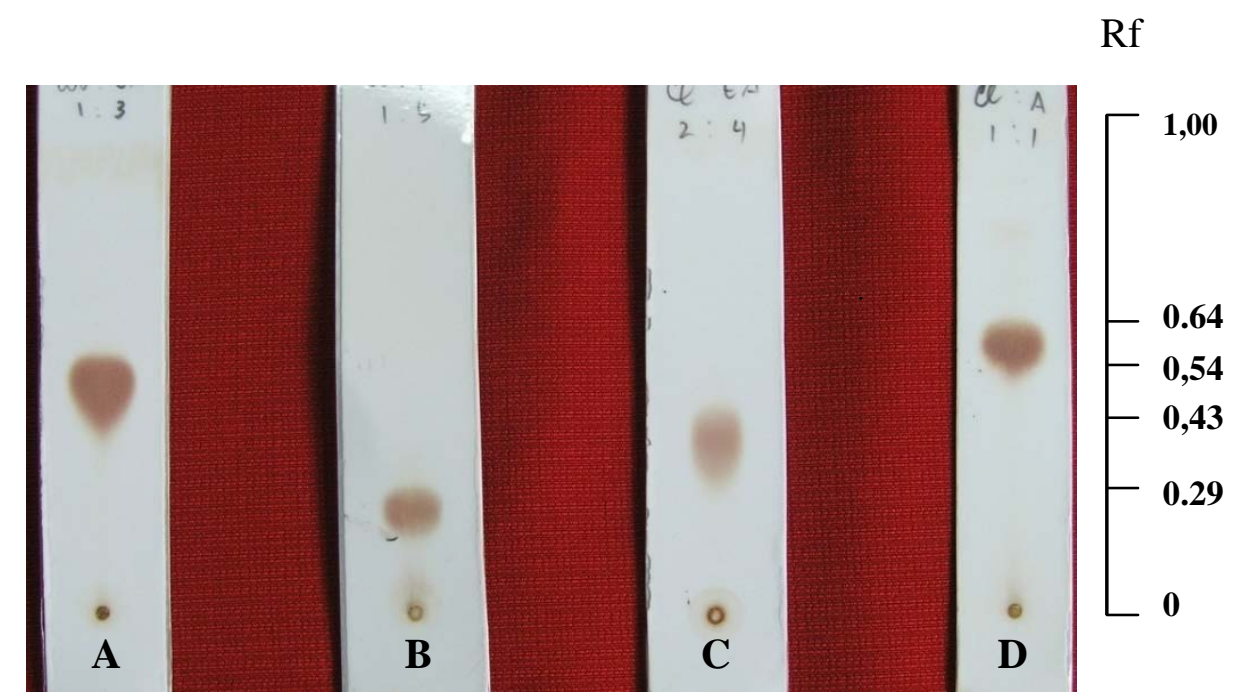

Gambar 5. Kromatografi lapis tipis senyawa hasil isolasi dengan menggunakan fase diam silika gel $\mathrm{GF}_{254}$ dan fase gerak yang berbeda-beda

Keterangan :
A. n-heksana : etil asetat $(2: 6 \mathrm{ml}+0,18 \mathrm{ml}$ asam asetat glasial $)$
B. n-heksana : aseton $(1,5: 7,5 \mathrm{ml}+0,2 \mathrm{ml}$ asam asetat glasial $)$
C. Kloroform : etil asetat ( $3: 6 \mathrm{ml}+0,2 \mathrm{ml}$ asam asetat glasial)
D. Kloroform : aseton $(4: 4 \mathrm{ml}+0,18 \mathrm{ml}$ asam asetat glasial)

D. Uji Aktivitas Senyawa Antifungal terhadap Ganoderma lucidum.

\section{1) Pengamatan makroskopis}

Hasil uji aktivitas senyawa antifungal terhadap Ganoderma lucidum hasil isolasi dapat dilihat pada Gambar 6. Pada konsentrasi 1800 $\mu \mathrm{g} / \mathrm{ml}$ terlihat zona penghambatan yang cukup jelas. Sedangkan pada konsentrasi yang lain zona penghambatan tidak terlihat. Pada penelitian ini dapat dikatakan bahwa secara in vitro, konsentrasi senyawa antifungal minimal yang diperlukan untuk menghambat pertumbuhan Ganoderma lucidum secara makroskopis adalah $1800 \mu \mathrm{g} / \mathrm{ml}$. 

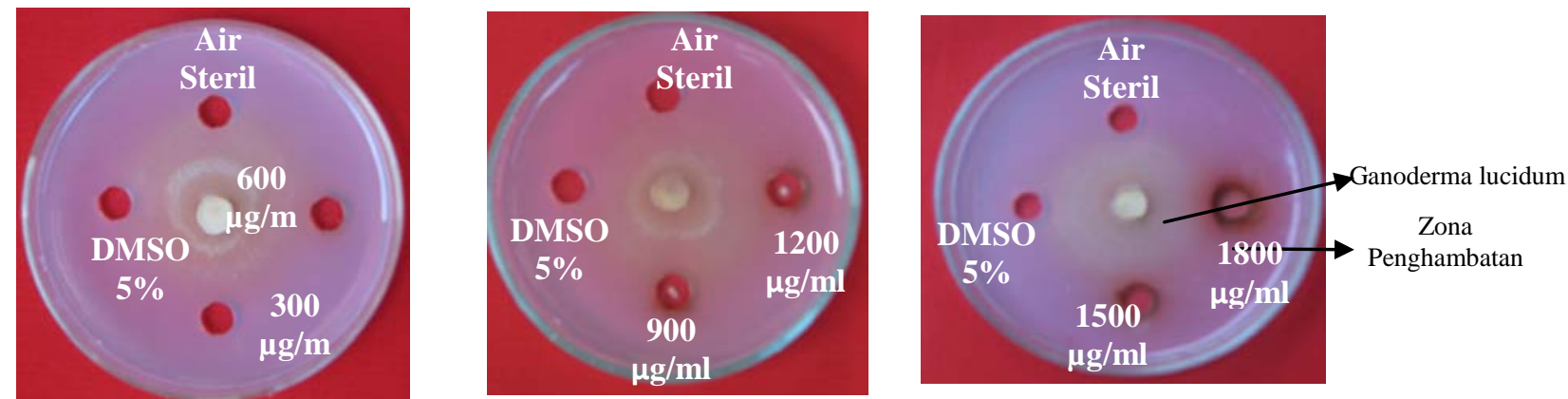

Gambar 6 . Aktivitas senyawa antifungal dalam menghambat pertumbuhan koloni Ganoderma lucidum pada berbagai konsentrasi $(\mu \mathrm{g} / \mathrm{ml})$

\section{2) Pengamatan mikroskopis}

Perkembangan hifa abnormal mulai teramati pada konsentrasi $1500 \mu \mathrm{g} / \mathrm{ml}$ sehari setelah aplikasi. Pada konsentrasi $1500 \mu \mathrm{g} / \mathrm{ml}$, dari gambar bisa dilihat adanya penyimpangan arah pertumbuhan hifa dan hifa yang berbentuk ikal pada ujungnya (Gambar 7). Penelitian yang dilakukan oleh Prapagdee et al., (2008) menunjukkan adanya hifa abnormal pada jamur Colletotrichum gloeosporoides dan Sclerotium rolfsii yang berupa pembengkakan dan penebalan pada ujung hifa serta adanya penyimpangan arah pertumbuhan hifa yang disebabkan pengaruh senyawa antifungal dari Streptomyces hygroscopicus.

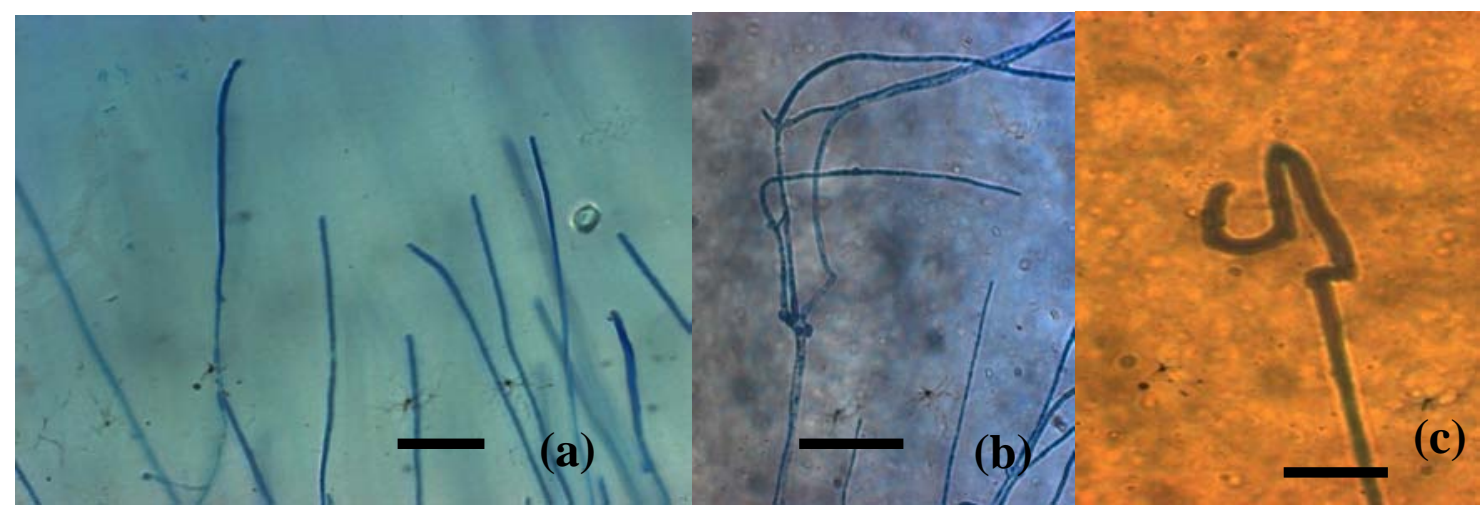

Gambar 7. Aktivitas senyawa antifungal hasil isolasi pada konsentrasi $1500 \mu \mathrm{g} / \mathrm{ml} 24$ jam setelah aplikasi (a) Hifa normal (kontrol); (b) Hifa yang mengalami penyimpangan arah pertumbuhan (bar : $20 \mu \mathrm{m}$ ); (c) Ujung hifa yang berbentuk ikal (bar : $40 \mu \mathrm{m}$ )

Pada aplikasi senyawa antifungal 2 hari setelah Trichophyton rubrum dan Penicillium marneffei aplikasi terlihat adanya hifa yang melilit pada mengalami pengerutan dan pelipatan pada hifa lain karena pengaruh aplikasi senyawa pertumbuhan hifanya karena pengaruh ekstrak antifungal (Gambar 8). Menurut Phongpaichit daun Cassia alata yang mengandung senyawa et al., (2004) hifa jamur Microsporum gyseum, yang bersifat antifungal. 


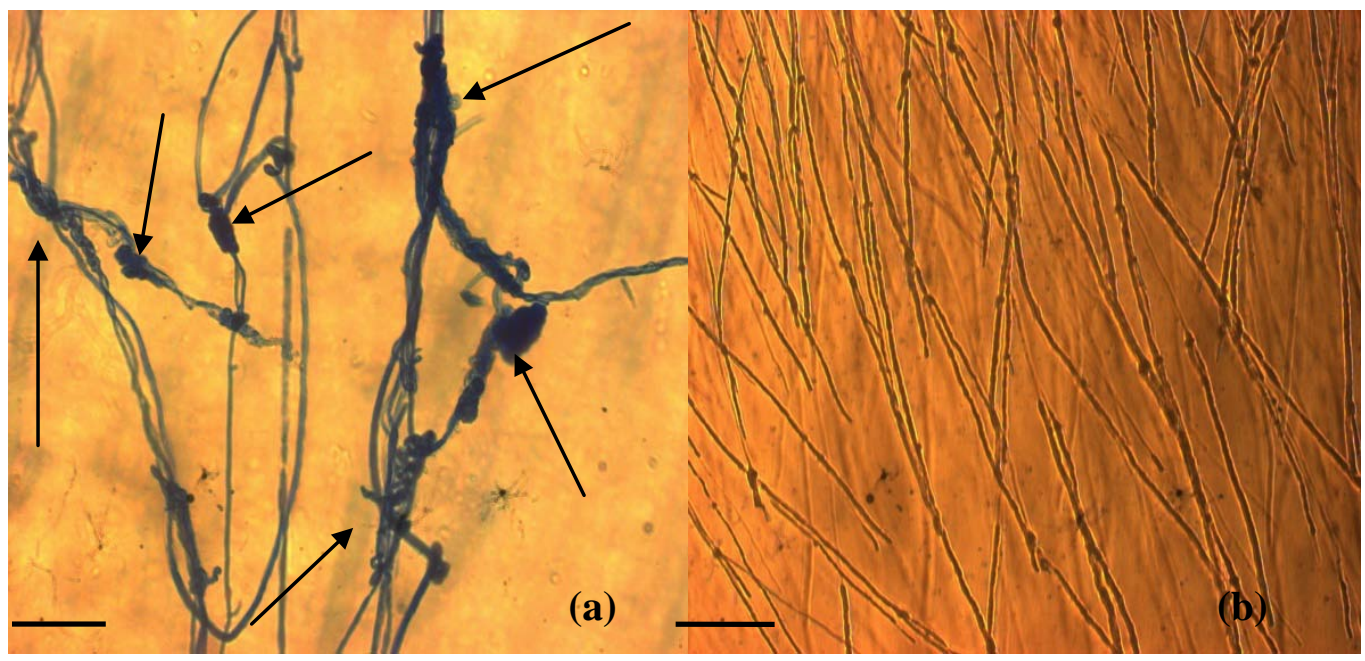

Gambar 8. Aktivitas senyawa antifungal konsentrasi $1800 \mu \mathrm{g} / \mathrm{ml}$ terhadap pertumbuhan hifa jamur Ganoderma lucidum 2 hari setelah aplikasi (a) Hifa yang melilit pada hifa lain karena pengaruh aplikasi senyawa antifungal; (b) Hifa normal tanpa aplikasi senyawa antifungal (bar : $20 \mu \mathrm{m}$ )

\section{E. Identifikasi Senyawa Antifungal \\ 1) Spektrum Ultraviolet (UV)}

Serapan yang ditunjukkan oleh senyawa antifungal ini adalah pada panjang gelombang 277 dan 340 nm (Gambar 9). Panjang gelombang ini merupakan panjang gelombang untuk golongan senyawa aromatik (Silverstein et al., 1981). Senyawa antifungal hasil isolasi akar mangium diduga termasuk ke dalam golongan aromatik.

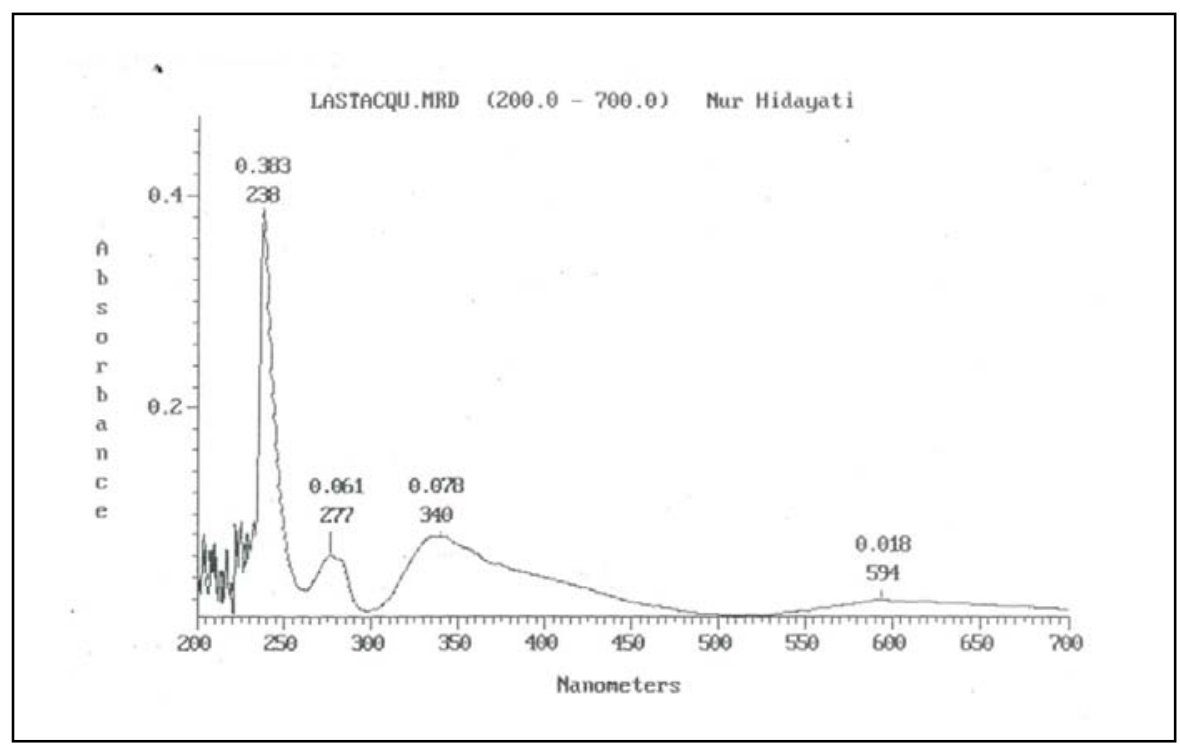

Gambar 9. Spektrum UV (MeOH) senyawa antifungal 


\section{2) Spektrum Inframerah (IR)}

Data spektroskopi IR (Gambar 10) menunjukkan data yang mengarah pada senyawa alkohol dan fenol. Pita yang melebar pada 3749-3425 $\mathrm{cm}^{-1}$ memberi indikasi adanya gugus hidroksil $(-\mathrm{OH})$, yang dipertegas dengan adanya pita pada $1300-1000 \mathrm{~cm}^{-1}$ yang menunjukkan adanya C-O. Spektrum infra merah alkohol pada konsentrasi yang rendah menunjukkan sebuah pita yang tajam pada 3650 $\mathrm{cm}^{-1}$ di samping adanya pita lebar tambahan pada $3350 \mathrm{~cm}^{-1} \quad$ (Sastrohamidjoyo, 2007). Puncak pada $1442 \mathrm{~cm}^{-1}$ mengindikasikan adanya tekukan -OH dalam bidang (Silverstein et al, 1981).

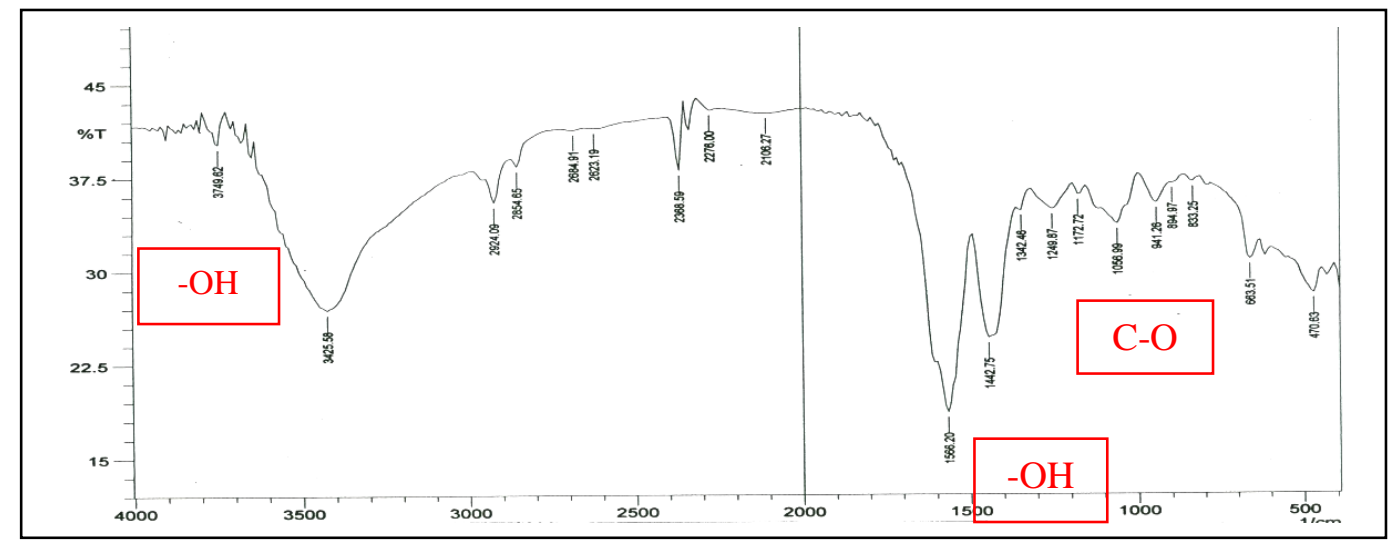

Gambar 10. Spektra IR (KBr) senyawa antifungal

\section{3) Gas Kromatografi-Spektrum (GC-MS)}

Hasil identifikasi dengan GC-MS menunjukkan bahwa hasil isolasi terdiri dari dua senyawa. Hal ini ditunjukkan dengan adanya dua puncak pada kromatogram gas. Puncak spektrum massa komponen pertama dengan persen area 1,83\% pada Rt 7,758. Pola spektrum massa ini jika dibandingkan dengan data base ada kemungkinan 2 senyawa yaitu suatu benzaldehyde dan vanilin. Pola spektrum massa yang mendekati pola spektrum massa sampel adalah benzaldehyde, puncak ion m/2 151 merupakan puncak ion molekul. Puncak spektrum massa komponen kedua pada Rt 17,14 menunjukkan komponen yang paling besar dengan persen area 98,17\%. Spektrum massa puncak ini memberi kemungkinan 2 senyawa berdasarkan atas spektrum massa data base, yaitu p-Methoxybenzylidene paminophenol yang termasuk dalam golongan senyawa fenolik dan 9H-Xanthen-9-one. Dari kedua senyawa ini, pola spektrum yang mendekati pola spektrum massa dari sampel adalah p-Methoxybenzylidene p-aminophenol yang termasuk golongan senyawa fenolik. Puncak pada m/z 227 merupakan puncak ion molekul (Gambar 14). 


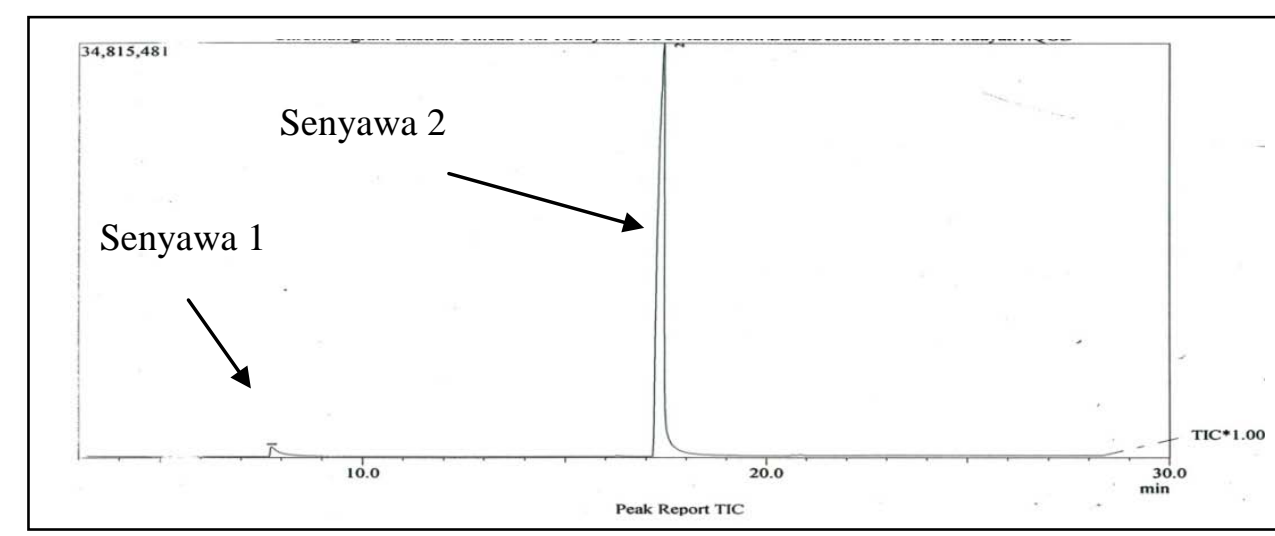

a

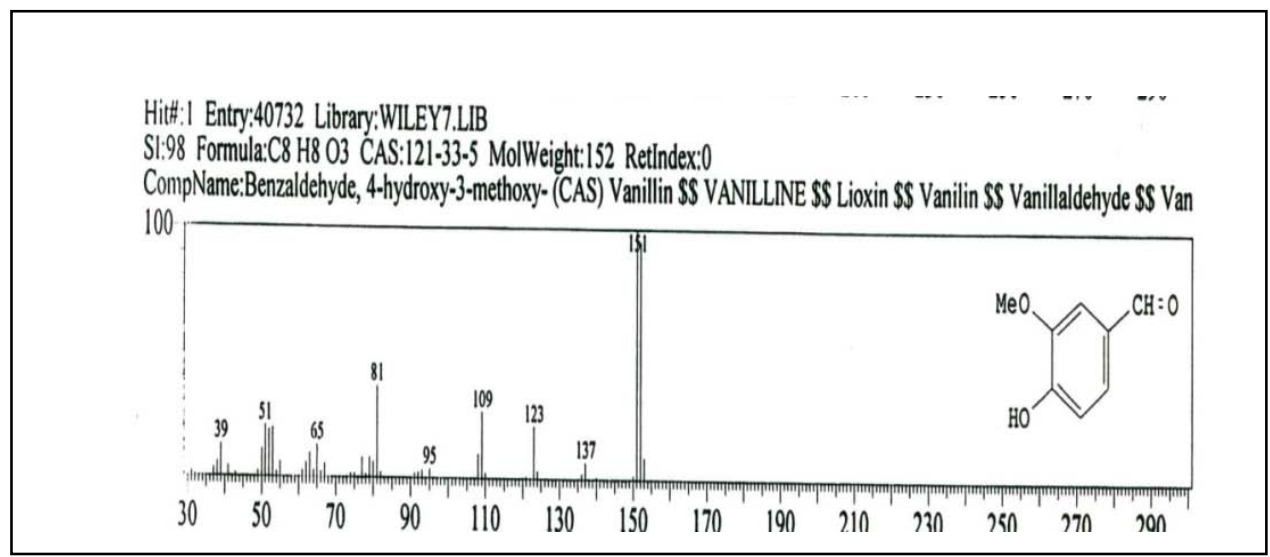

b

Hitt:I Entry:129890 Library:WILEY7.LBB

Sl:78 Formula:C14 HI3 N 02 CAS:3230-39-5 MolWeight:227 Rettndex:0

CompName:Phenol, 4-[[(4-methoxyphenyl)methylene]amino]- S\$ p-Methoxybenzylidene p-aminophenol S\$ p-[(p-Methoxybenzylic

100

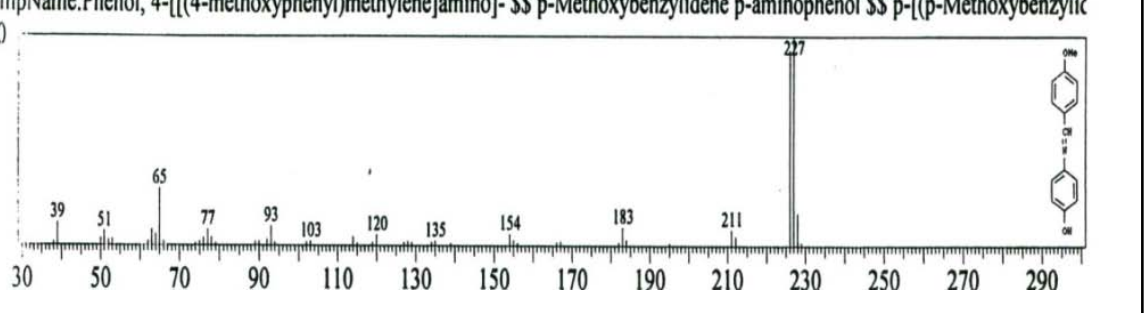

C

Gambar 11. (a) Gas Kromatogram dari Spektra GC-MS senyawa antifungal; (b) Spektra massa senyawa 1; (c) Spektra massa senyawa 2

Kandungan metabolit sekunder pada tanaman antibakterial dan antivirus pada tanaman dianggap penting sebagai penyebab ketahanan (Gogoi et al., 2001). Senyawa ini berperan besar tanaman terhadap penyakit. Senyawa yang dalam mekanisme pertahanan tanaman terhadap diduga terlibat di dalamnya adalah senyawa beberapa patogen penyebab penyakit (Badra dan fenol, misalnya loridzin dalam apel dan tanin Elgindi, 1979).

dalam frambus (Harborne, 1996). Senyawasenyawa fenolik diketahui bersifat antifungal, 


\section{KESIMPULAN}

Akar tanaman mangium dari kebun benih generasi pertama di Wonogiri, Jawa Tengah mempunyai senyawa yang bersifat antifungal terhadap jamur Ganoderma lucidum. Dengan spektroskopi GC-MS, senyawa ini teridentifikasi sebagai pMethoxybenzylidene p-aminophenol yang termasuk dalam golongan senyawa fenolik.

\section{UCAPAN TERIMA KASIH}

Tulisan ini merupakan bagian dari tesis S2 penulis pada PAU Bioteknologi, Sekolah Pasca Sarjana, Universitas Gadjah Mada. Ucapan terima kasih penulis sampaikan kepada Balai Besar Penelitian Bioteknologi dan Pemuliaan Tanaman Hutan, Badan Litbang Kehutanan dan Tanoto Foundation atas terlaksananya penelitian ini.

\section{DAFTAR PUSTAKA}

Abad, M.J., M. Ansuategui, dan P. Bermejo. 2007. Active Antifungal Substances from Natural Sources. http://www.arkatusa.org/ARKIVOC/JOURNAL_CONTENT. Download : 23 April 2008.

Agrios, G.N. 2005. Plant Pathology. Fifth Edition. Academic Press. San Diego. USA.

Badra,T., dan D.M. Elgindi. 1979. The Relationship between Phenolic Content and Tylenchulus semipenetrans Populations in Nitrogen-Amended Citrus Plants. Revue Nematology 2 : 161-164.

Cannell, J.P.R. 1998. Natural Products Isolation. Humana Press Inc. New Jersey.

Chang, S.T., J.H. Wu, S.Y. Wang, P.L. Kang, N.S. Yang, dan L.F. Shyur. 2001. Antioxidant Activity of Extracts from Acacia confuse Bark and Heartwood. Journal Agriculture Food Chemistry 49 : 3420 - 3424.
Gogoi, R., D.V. Singh, dan K.D. Srivastara. 2001. Phenols as a Biochemical Basis of Resistance in Wheat Againts Karnal Bunt. Journal of Plant Pathology $50: 470-476$.

Gritter, R.J., J.M. Bobbit, dan A.E. Schwarting. 1991. Pengantar Kromatografi. Diterjemahkan oleh Kosasih Padmawinata. Penerbit ITB. Bandung.

Hagerman, A.F., K.M. Riedl, A. Jones, K.N. Sovik, N.T. Ritchard, P.W. Hartzfeld, dan T.L. Riechel. 1998. High Molecular Weight Plant Polyphenols (Tannins) as Biological Antioxidant. Journal Agriculture Food Chemistry 46 : 1887 - 1892.

Harborne, J.B. 1996. Metode Fitokimia : Penuntun Cara Modern Menganalisis Tumbuhan, diterjemahkan oleh Kosasih Padmawinata dan Iwang Soediro. Terbitan Kedua. Penerbit ITB. Bandung.

Haslam, E. 1988. Plant Polyphenols (syn. Vegetable Tannins) and Chemical Defence a Reappraisal. Journal Chemical Ecology 14 : 1789 - 1806.

Johnson, L.F., dan E.A. Curl. 1972. Methods for Research on The Ecology of Soil-Borne Plant Pathogen. Burgess Publishing Company. Minnesota.

Kishino, M., H. Ohi, dan A. Yamaguchi. 1995. Characteristics of Methanol Extractives from Chengal Wood and Their Antifungal Properties (in Japanese). Mokuzai Gakkaishi 41 : 444 - 447.

Mila, I., A. Scalbert, dan D. Expert. 1996. Iron Withholding by Plant Pathogens and Resistance to Pathogens and Rots. Journal of Phytochemistry $42: 1551-1555$.

Moffat, A.C. 1986. Thin Layer Chromatography dalam Clarkes Isolation and Identification of Drugs. Edisi Kedua. The Pharmaceutical Press. London.

Morrisey, J.P., dan A.E. Osbourn. 1999. Fungal Resistance to Plant Antibiotics as a Mechanism of Pathogenesis. Microbiology and Molecular Biology Reviews 63 : 708 - 724.

Phongpaichit, S., N. Pujenjob, V. Rukachaisirikul, dan M. Ongsakul. 2004. Antifungal Activity from Leaf Extracts of Cassia alata L., Cassia fistula L. and Cassia tora L. Journal of Science and Technology 26 : 741 - 748.

Prapagdee, B., C. Kuekulvong, dan S. Mongkolsuk. 2008. Antifungal Potential of Extracellular Metabolites Produced by Streptomyces hygroscopicus Against Phytopathogenic Fungi. Journal of Biological Sciences 4 : 330 - 337.

Rimbawanto, A. 2006. Busuk Hati di Hutan Tanaman : Latar Belakang dari Proyek ACIAR. Lokakarya Busuk Hati dan Busuk Akar pada Hutan Tanaman Akasia. Yogyakarta, 7-9 Februari 2006.

Sastrohamidjojo, H. 2007. Spektroskopi. Liberty. Yogyakarta.

Scalbert, A. 1991. Antimicrobial Properties of Tannins. Journal of Phytochemistry 30 : 3875 - 3883. 
Silverstein, R.M., G.C. Bassler, dan T.C. Morrill. 1981. Penyidikan Spektrometrik Senyawa Organik. Edisi Keempat. Diterjemahkan oleh A.J. Hartomo. Erlangga. Jakarta.

Sjostrom, E. 1998. Kimia Kayu. Dasar-Dasar dan Penggunaan. Edisi Kedua. Diterjemahkan oleh Hardjono Sastrohamidjojo. Gadjah Mada University Press. Yogyakarta.

Sukadana, I.M., S.R. Santi, dan N.K. Juliati. 2008 Aktivitas Antibakteri Senyawa Golongan Triterpenoid dari Biji Pepaya (Carica papaya L.). Jurnal Kimia $2: 15-18$.

Waters, D. 1985. Waters Sourcebook for Chromatography Columns and Supplies. Waters Chromatography Division. USA.

Widyastuti, S.M., Sumardi, dan D. Puspitasari. 1998. Uji Kemampuan Penghambatan Ekstrak Biji Nyiri (Xylocarpus granatum) terhadap Jamur Benih Tanaman Kehutanan. Bulletin Kehutanan 37 : 2 $-9$

Widyastuti, S.M. 2001. Fitoaleksin dan Resistensi. Program Studi Bioteknologi. Program Pasca Sarjana. UGM. Yogyakarta. 